De Jure: Jurnal Hukum dan Syari'ah

Vol. 11, No. 1, 2019, h. 36-47

ISSN (Print): 2085-1618, ISSN (Online): 2528-1658

DOI: http://dx.doi.org/10.18860/j-fsh.v11i1.6328

Available online at http://ejournal.uin-malang.ac.id/index.php/syariah

\title{
Praktik Poligami Tanpa Izin Pengadilan Agama Palembang
}

\author{
Meriyati \\ Sekolah Tinggi Ekonomi dan Bisnis Syariah Indo Global Mandiri Palembang \\ meri@stebisigm.ac.id \\ Mustamiruddin \\ Sekolah Tinggi Ekonomi dan Bisnis Syariah Indo Global Mandiri Palembang \\ tamirudin_2002@yahoo.com
}

\begin{abstract}
Abstrak
The Islamic Law allows Marriage a husband to commit polygamy as well as a condition is able to be fair on his wives, however, The spiritual and happiness perfection sometimes cannot be enforced by legal force existing. The Polygamy is the last resort of an emergency nature. This research is descriptive analytical and uses a juridical normative approach with building Win solution (Maslahah) theory, enforcement and legal compliance. The theory was used as a way to find answers of existing problems. The goal of this study aims to make clean the controversial phenomenon between the ideals of the rule of law and the realities society those are not always compactable. The results of research on polygamy practice at religious court of Regional Palembang were made to find out that the practice of polygamy cases that was occurred among the community proven without involving the court was resulted in the loss of livelihood or sustenance for wife and descent abandoned.
\end{abstract}

Hukum Perkawinan Islam memperbolehkan seorang suami melakukan poligami dengan syarat mampu berlaku adil terhadap isteri-isterinya, akan tetapi, kesempurnaan dan kebahagian rohani terkadang tidak dapat dipaksakan oleh kekuatan hukum yang ada. Poligami merupakan jalan terakhir yang sifatnya darurat. Penelitian ini bersifat deskriptif analitis dan menggunakan pendekatan normatif yuridis dengan bangunan teori maslahah, penegakan dan ketaatan hukum. Teori tersebut digunakan sebagai jalan untuk mencari jawaban atas permaslahan yang ada. Penelitian ini bertujuan sebagai pengungkapan fenomenan yang kontroversial antara idealitas aturan hukum dan realitas yang ada dalam masyarakat yang berlaku tidak selalu sejalan. Hasil dari penelitian praktek poligami tanpa izin pengadilan agama Palembang ini dibuat untuk mengetahui bahwa praktek kasus poligami yang terjadi di kalangan masyarakat terbukti tanpa melibatkan pihak pengadilan yang mengakibatkan ketersendatan nafkah yang diberikan pada istri dan keturunan yang ditinggalkan.

Kata Kunci: poligami; perkawinan; nafkah 


\section{Pendahuluan}

Perkawinan dibawah tangan tanpa melibatkan aparatur pemerintah, baik KUA ataupun Pengadilan Agama menjadi masalah tersendiri bagi masyarakat. Akan tetapi paradigma tersebut seakan tidak pernah usai. Bahkan ada sebagian remaja yang melakukan observasi sampai seberapa jauh diantara mereka terdapat keserasian paham, baik secara ideal maupun secara praktis dalam membina rumah tangga. Untuk itu mereka melakukan proof marriage (kawin percobaan) dalam jangka waktu tertentu. Bila dalam masa waktu tertentu terdapat keserasian masalah hobi dan sex, maka mereka akan meningkatkan dalam hubungan perkawinan resmi, namun jika yang terjadi adalah sebaliknya, maka mereka akan mencari pasangan baru sesuai dengan type yang mereka inginkan. ${ }^{1}$ Nabi Muhammad S.A.W. diutus untuk menyampaikan risalah Ilahiah kepada umatnya dengan membawa misi rahmatan-lil- 'alamin (kasih sayang kepada seluruh alam semesta).

Salah satu bentuk rahmat tersebut adalah dengan disyariatkannya perkawinan. Perkawinan merupakan aspek yang penting dalam kehidupan manusia. al-Qur'an banyak berbicara masalah keluarga dan perkawinan. Keseluruhan ayat tersebut memberikan tuntutan kepada manusia dalam membina keluarga (rumah tangga) agar tercipta kehidupan keluarga sakinah, mawaddah, warahmah yang diridhai Allah. Umumnya para remaja, bila telah menginjak umur dewasa biasanya akan berangan-angan untuk hidup berumah tangga. ${ }^{2}$ Dalam agama, suatu keluarga dimulai dengan adanya nikah atau perkawinan, yaitu suatu akad yang kokoh (mitsaqon ghalizan) antara seorang laki-laki dan perempuan dengan memenuhi syarat dan rukun perkawinan. Melalui lembaga perkawinan, hubungan antara seorang laki-laki dan perempuan yang bukan mahramnya menjadi sah. ${ }^{3}$

Perkawinan dapat menyelamatkan masyarakat dari ancaman dekadensi moral. Di samping itu, melalui perkawinan masyarakat akan mampu mengamankan individu dari kejahatan sosial, karena tabiat manusia yang tertarik dengan lawan jenis tersalurkan melalui jalan perkawinan. Rasulullah S.A.W pernah mengarahkan kepada para pemuda mengenai urgensi perkawinan: "Wahai sekalian pemuda, barangsiapa yang telah mampu melakukan perkawinan, maka kawinlah, sebab kawin bisa memelihara pandangan dan menjaga kemaluan". ${ }^{4}$ Dalam ranah pernikahan, sedikit banyak akan dibahas perkara poligami. Problematika poligami selalu memicu reaksi keras dan menjadi isu meresahkan terutama di kalangan perempuan, karena manusia itu bersifat human nature yaitu mempunyai watak cemburu, iri hati, dan suka mengeluh. Sebagian besar orang masih memandang keluarga poligami dengan stigma negatif. ${ }^{5}$

Keluarga dari perkawinan poligami sampai detik ini masih identik dengan stereotipe bahwa keluarga semacam itu tidak akan bisa hidup rukun dan dicap sebagai orang yang mau ingin enak sendiri sehingga muncul keprihatinan bahwa kemungkinan ada pemahaman yang pro dan kontra terhadap isu yang sensitif ini. Akibatnya, banyak orang yang merasakan sangat sulit untuk mengakui dukungan mereka terhadap poligami atau bahkan mengakui keinginan mereka untuk memiliki isteri lagi dengan niat yang baik, karena takut dicap dengan label-label yang buruk. Poligami atau menikahi dari seorang

\footnotetext{
${ }^{1}$ Idris Ramulyo, Hukum Perkawinan Islam, (Jakarta: Bumi Askara, 1996), 39

${ }^{2}$ Nazwier D. Snardjo, dan Ilyas, Yusrani, Tuntunan Keluarga, (Jakarta: Kalam Mulia, 1992), 23

${ }^{3}$ Duski Ibrahim, "Keluarga Sebagai Basis Kependudukan," Sumatera Express, 6 Desember 2013..

${ }^{4}$ Abdullah Nasikh Ulwan, Pendidikan Anak dalam Islam, (Jakarta: Pustaka Amani, 2007), 13

${ }^{5}$ Abdurrahaman Gazaly, Fiqih Munakahat, (Bogor: Kencana, 2003), 132
} 
istri bukan merupakan masalah baru, ia telah ada dalam kehidupan manusia sejak dulu kala diantara berbagai kelompok masyarakat dunia. ${ }^{6}$

Menurut Musfir Al-Jahrani, ${ }^{7}$ sudah menjadi kenyataan yang patut disesalkan bahwa dewasa ini sebagian kaum muslimin menentang poligami. Seseorang yang berkeinginan untuk berpoligami sering sekali dituding sebagai pemborosan harta, sebagian lagi dituduh sebagai pengumbar hawa nafsu syahwat yang berlebihan, dan sebagian orang datang menasihatinya agar dia membatalkan niat poligaminya. Bagi mereka yang berbeda kewarganegaraan dan akan melangsungkan perkawinan, di mana salah satunya berkewarganegaraan Indonesia, maka perkawinan tersebut dapat dikatakan sah sepanjang telah dilangsungkan dan tunduk pada persyaratan dalam Undang-Undang Perkawinan. Pada intinya perkawinan yang sah tersebut harus memenuhi unsur yang terdapat pada ketentuan Pasal 2 Undang-Undang Perkawinan, yaitu: “(1) Perkawinan adalah sah, apabila dilakukan menurut hukum masing-masing agamanya dan kepercayaannya tersebut. (2). Tiap-tiap perkawinan dicatat menurut peraturan perundang-undangan yang berlaku". 8

Bila dilihat dari sudut pandang laki-laki, bagi mereka yang mampu tentu tidak akan merugikan. Namun, bila dilihat dari sudut kepentingan perempuan, kiranya hampir tidak ada yang menguntungkan bagi perempuan, karena ditinjau dari sudut psikologis, jarang sekali perempuan yang rela dimadu, pada umumnya dalam masyarakat bahwa laki-laki lebih menggunakan logika sedangkan perempuan lebih menggunakan perasaan. Berangkat dari kepentingan perempuan itulah jarang dijumpai adanya perkawinan poligami yang mendapat izin dari isteri, terlebih apabila isteri dapat menjalankan kewajibannya sebagai isteri dengan sempurna, tidak memiliki cacat. ${ }^{9}$ Menurut uraian di atas dapat disimpulkan bahwa pada dasarnya seseorang yang akan melangsungkan suatu perkawinan diharuskan mendaftarkan diri terlebih dahulu, maksudnya agar lebih mengetahui dengan jelas identitas diri. Bukti yang menerangkan identitas diri adalah Kartu Tanda Penduduk (KTP) dan surat yang diminta dari kepala desa atau kantor kelurahan setempat dimana perkawinan akan dilaksanakan dan apabila paracalon akan melaksanakan perkawinan di luar daerah, maka orang tuanya akan diminta hadir untuk memberikan keterangan dari mereka yang akan melaksanakan perkawinan tersebut. ${ }^{10}$

Kewajiban perkawinan yang akan dilaksanakan dengan menggunakan surat keterangan tentang status diri sebenarnya berfungsi untuk menghindari resiko yang bisa merugikan kedua pihak. Adanya perbedaan fakta antara data yang tertera dengan kenyataan merupakan bentuk tidak terpenuhinya syarat perkawinan yang dapat merugikan pihak lain. Perihal penelitian yang terkait dengan praktek poligami ini pernah dilakukan oleh Nur Khoirin ${ }^{11}$ yang menyatakan izin poligami bagi Pegawai Negeri Sipil (PNS) tidak perlu mendapat izin dari pimpinan, karena menikah adalah urusan keluarga

\footnotetext{
${ }^{6}$ Abdurahman, Perkawinan Dalam Syari'at Islam, (Jakarta: Renika Cipta \& Melton Putra, 1992), 43

${ }^{7}$ Rigoto, Suten. 1996. Poligami dari Berbagai Persepsi, (Jakarta: Gema Insani Press), 38

${ }^{8}$ Undang-Undang Nomor 1 Tahun 1974 tentang Perkawinan LN. Tahun 1974 No. 1

${ }^{9}$ Rani Alfianty, "Pembatalan Perkawinan Poligami Beda Kewarganegaraan Tanpa Izin Isteri Disertai Dengan Pemalsuan Identitas (Studi Kasus Putusan Pengadilan Agama Depok Nomor 324/Pdt.G/2006/PA.Dpk) (Tesis, Universitas Indonesia, 2011)

10 Departemen Agama, Pedoman Pembantu Pegawai Pencatat Nikah: Proyek Peningkatan Tenaga Keagamaan Direktorat Jendral Bimbingan Masyarakat Islam dan Penyelengaraan Haji Departemen Agama RI (Jakarta: Departemen Agama RI, 2004)

${ }^{11}$ Nur Khoirin, "Menyoal izin Poligami bagi PNS," YINYANG Jurnal Studi Gender dan Anak 5, no. 2 (2010): 227-242, https://doi.org/10.24090/yy.v5i2.2010.pp227-242
} 
dan pimpinan bukan bagian dari unsur keluarga. Sedangkan Yohanis ${ }^{12}$ dalam penelitiannya menyebutkan bahwa praktek poligami di wilayah kota Padang berjalan dengan baik karena mengintegrasikan antara syarat ketentuan dari agama (hukum Islam) dan negara (hukum positif).

\section{Metode Penelitian}

Penelitan ini merupakan pemikiran sistematis untuk memperoleh data-data, kemudian mengembangkan dan menguji kebenaran suatu pengetahuan. Berkaitan dengan penelitian ini, maka metodelogi yang digunakan untuk mendiskripsikan atau menemukan fakta-fakta yang ada di Pengadilan Agama kelas 1A Palembang, terutama yang berkaitan dengan Perkara Poligami. Kajian ini menggunakan metode penelitian kualitatif. Metode kualitatif merupakan sebagai prosedur penelitan yang menghasilkan data perilaku yang dapat diamati. ${ }^{13}$ Dengan metode ini peneliti dapat menyajikan secara langsung hubungan antara peneliti dan responden, sehingga dapat menjawab permasalahan-permasalahan yang diteliti. Analisis yang digunakan dalam penelitian ini bersifat deskriptif analitis dan menggunakan pendekatan normatif yuridis dengan bangunan teori maslahah, penegakan dan ketaatan hukum. Teori tersebut digunakan sebagai jalan untuk mencari jawaban atas permaslahan yang ada. Pengambilan data dalam penulisan ini melalui wawancara kepada para hakim dan panitera di Pengadilan Agama serta menganalisis terhadap produk hakim berupa putusan-putusan di Pengadilan Agama Palembang yang berkaitan dengan poligami.

\section{Hasil dan Pembahasan \\ Tinjauan Histori dan Konsep Dasar Izin Poligami}

Dalam suatu penelitian diperlukan kerangka teori untuk dijadikan kerangka berpikir dengan mengetengahkan konsep-konsep pemikiran para pakar hukum. Adapun penelitian yang kami sajikan ini berkaitan dengan norma penegakan hukum yang telah ditetapkan, mengingat banyaknya pelanggaran yang dilakukan oleh masyarakat dikarenakan lemahnya para penegak hukum yang ada. Sebagaimana yang tertera dalam UndangUndang No. 1/1974 tentang perkawinan dalam bab IX pasal 57 yang merupakan syarat bagi suami untuk melakukan poligami. Namun realitanya banyak masyarakat tidak mentaati peraturan yang tertuang pada undang-undang tersebut, karena tidak sesuai dengan fitrah manusia yang memperbolehkan untuk berpoligami.

Dalam prakteknya, banyak orang yang hendak berpoligami namun tidak memenuhi syarat yang ditetapkan oleh Undang-Undang, ahkirnya mereka mengambil jalan pintas dengan melakukan pernikahan sirri. Untuk menyatukan dan mengambil kesimpulan dari berbagai landasan poligami yang memicu terwujudnya pelanggaran-pelanggaran yang ada pada hukum perkawinan, maka peneliti akan menganalisis sumber-sumber yang berkaitan dengan hukum pernikahan itu sendiri. Hukum merupakan sistem yang telah ditetapkan dan diberlakukan sesuai dengan kesepakatan yang harus ditaati dan dihormati. Menurut teori Lawrence Meir Friedman dalam jurnal Lianora, ${ }^{14}$ bahwasanya hukum

\footnotetext{
12 Yohanis, "Perkawinan Poligami di Wilayah Hukum Pengadilan Agama Kota Padang (Mekanisme Pemberian Izin, Dasar Hukum, Syarat-Syarat Poligami dan pelaksaannya" Soumatera Law Review 1 no. 1 (2018): 198-217, https://doi.org/10.22216/soumlaw.v1i1.3403

${ }^{13}$ Lexy Moleong J, Metode Penelitian Kualitatif, (Bandung: Percetakan Rusda, 1991), 3

${ }^{14}$ Lianora Sinaga dkk, "Penegakan Hukum Penyalahgunaan Izin Tinggal Orang Asing di Kota Palu (Studi Kasus Di Imigrasi Klas I Palu)” Legal Opinion: Jurnal Ilmu Hukum 6, no. 3 (2018): 195
} 
harus berjalan seirama dengan keadilan, maka hukum yang dibentuk harus berjalan efektif dan memberikan rasa keadilan bagi masyarakat itu sendiri.

Eropa Kontinental (meski sebagaian peraturan perundang-undangan juga telah menganut Common Law System atau Anglo Saxon) menyebutkan hukum adalah peraturan-peraturan yang tertulis sedangkan peraturan-peraturan yang tidak tertulis bukan dinyatakan hukum. Sistem ini mempengaruhi sistem hukum di Indonesia. Salah satu pengaruhnya adalah adanya asas Legalitas dalam KUHP. Dalam Pasal 1 KUHP ditentukan "tidak ada suatu perbuatan pidana yang dapat di hukum jika tidak ada aturan yang mengaturnya". Sehingga bisa atau tidaknya suatu perbuatan dikenakan sanksi hukum apabila perbuatan tersebut telah mendapatkan pengaturannya dalam perundangundangan. Berikut tabel yang disajikan:

Bagan 1. Sistem Hukum

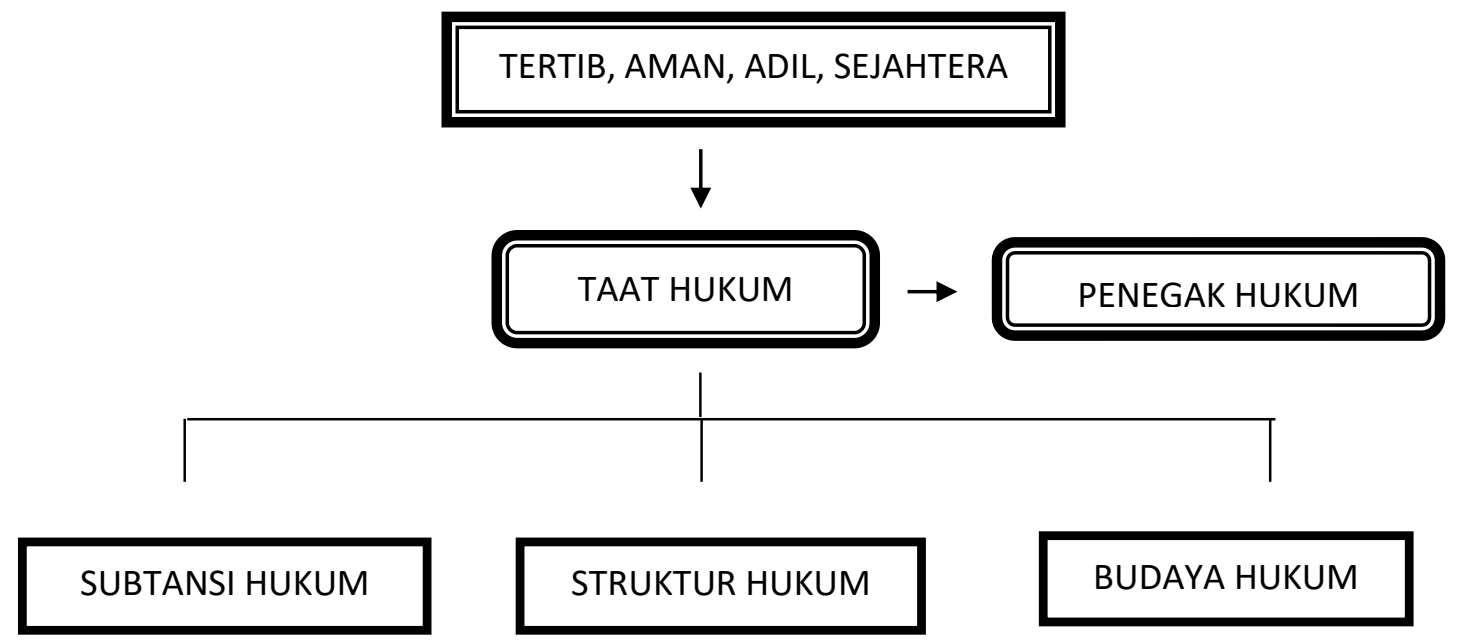

Sumber: Teori Lawrence Meir Friedman.

Struktural juga menentukan bisa atau tidaknya hukum itu dilaksanakan dengan baik. Struktur hukum berdasarkan UU No. 8 Tahun 1981 meliputi: mulai dari Kepolisian, Kejaksaan, Pengadilan dan Badan Pelaksana Pidana (Lapas). Kewenangan lembaga penegak hukum dijamin oleh undang-undang. Sehingga dalam melaksanakan tugas dan tanggungjawabnya terlepas dari pengaruh kekuasaan pemerintah dan pengaruh-pengaruh lain. Terdapat adagium yang menyatakan "fiat justitia et pereat mundus"(meskipun dunia ini runtuh hukum harus ditegakkan). Hukum tidak dapat berjalan atau tegak bila tidak ada aparat penegak hukum yang kredibilitas, kompeten dan independen. Dapat kita simpulkan seberapa bagusnya suatu peraturan perundang-undangan bila tidak didukung dengan aparat penegak hukum yang baik maka keadilan hanya menjadi angan-angan saja. Lemahnya mentalitas aparat penegak hukum mengakibatkan penegakkan hukum tidak berjalan sebagaimana mestinya. Banyak faktor yang mempengaruhi lemahnya mentalitas aparat penegak hukum di antaranya lemahnya pemahaman agama, ekonomi, proses rekruitmen yang tidak transparan dan lain sebagainya.

Sehingga dapat dipertegas bahwa faktor penegak hukum memainkan peran penting dalam memfungsikan hukum. Kalau peraturan sudah baik, tetapi kualitas penegak hukum rendah maka akan ada masalah. Demikian juga, apabila peraturannya buruk sedangkan kualitas penegak hukum baik, kemungkinan munculnya masalah masih terbuka. Kultur budaya hukum erat kaitannya dengan kesadaran hukum masyarakat. Semakin tinggi 
kesadaran hukum masyarakat maka akan tercipta budaya hukum yang baik dan dapat merubah pola pikir masyarakat mengenai hukum yang berlaku selama ini.

Secara sederhana, tingkat kepatuhan masyarakat terhadap hukum merupakan salah satu indikator berfungsinya hukum, baik substansi hukum, struktur hukum maupun budaya hukum saling keterkaitan antara satu dengan yang lain dan tidak dapat dipisahkan. Dalam pelaksanaannya di antara ketiganya harus tercipta hubungan yang saling mendukung agar tercipta pola hidup aman, tertib, tentram dan damai. Dalam teori hukum murni, (The Pure Theory of Law) bahwa hukum itu harus dibersihkan dari unsur-unsur yang tidak yuridis seperti etis, sosiologis, politis dan sebagainya. ${ }^{15}$ al-Qur'an menjelaskan secara gamblang tentang penegakan hukum, dalam surat: al-Mai'dah ayat: 3. Sedangkan Pancasila meletakkan nilai ketuhanan dan keadilan secara berurutan, yaitu sila pertama dan kedua. Oleh karenanya, ketuhanan dan keadilan sejatinya menjadi darah yang mengalir deras di dalam tubuh setiap anak bangsa, terutama di kalangan para penegak hukum, hingga mereka tidak melakukan hal-hal yang bisa menghancurkan penegakan hukum dan kehidupan berbangsa secara umum. Dari keterangan di atas dapat dipahami bahwa adanya suatu pelanggaran dalam hukum pernikahan poligami bisa saja terjadi dari pihak pelaku itu sendiri dan tidak menutup kemungkinan hal itu terjadi atas lemahnya penegak hukum yang ada, maka yang terjadi dimasyarakat kesemena-menaan pelaku dalam melanggar hukum yang telah ditetapkan.

\section{Penyelesaian Kasus Praktek Poligami Tanpa Izin Pengadilan Di Palembang}

Penyebab suami melakukan poligami tanpa izin pengadilan dalam Undang-undang Perkawinan No. 1 tahun 1974 pasal (4) menjelaskan bahwa bagi suami yang berkeinginan melakukan poligami hendaklah mengajukan permohonan ke pengadilan Agama dengan alasan yang dibenarkan oleh Undang-undang perkawinan, yaitu: 1. Jika isteri tidak dapat menjalankan kewajiban sebagai isteri, 2. Jika isteri mendapat cacat badan atau penyakit yang tidak dapat disembuhkan, 3. Jika isteri mandul/tidak dapat melahirkan keturunan. Alasan poligami pada point pertama menunjukkan hal yag bersifat umum sehingga perlu ditekankan dengan adanya fakta hukum yang menunjukkan bahwa isteri tidak dapat menjalankan kewajibannya sebagai seorang isteri, sehingga mengakibatkan sang suami perlu beristeri lagi untuk memenuhi kebutuhan suami yang tidak dapat dilaksanakan oleh isterinya, misalnya isteri sulit dan tidak mau melayani kebutuhan biologis sang suami atau isteri tidak dapat memenuhi kebutuhan lainnya yang hal itu dapat terpenuhi jika sang suami tersebut menikah dengan wanita lain.

Pada pasal 5 ayat 1 UU No.1 Tahun 1974 dinyatakan bahwa permohonan poligami dapat diajukan kepengadilan dengan syarat-syarat tertentu yaitu: 1. Adanya persetujuan dari Isteri, 2) Adanya kepastian bahwa suami mampu menjamin keperluan-keperluan hidup isteri-isteri dan anak-anak mereka, 3) Adanya jaminan bahwa suami akan berlaku adil terhadap isteri-isteri dan anak-anak mereka. ${ }^{16}$ Persetujuan isteri dapat diajukan secara tertulis dan dapat pula disampaikan secara lisan di muka sidang pengadilan. Pemberian izin poligami tidak memerlukan syarat atau persetujuan isteri, jika dalam keadaan isteri tidak mungkin diminta persetujuan baik karena sakit jiwa ataupun Mafqudoh (tidak ada kabar dua tahun berturut-turut) atau karena sebab lain menurut penilaian hakim. Dalam

\footnotetext{
15 Jimly Asshiddiqie dan Ali Safa'at, Teori Hans Kelsen Tentang Hukum (Jakarta: Setjen \& Kepaniteraan MK-RI, 2006), 11

${ }^{16}$ Direktorat Jendral Bimbingan Masyarakat Islam Kementerian Agama Republik Indonesia. Himpunan Peraturan Perundang-Undangan Perkawinanan. (Jakarta: Kementerian Agama RI, 2010), 28
} 
pasal 41 Peraturan Pemerintah No. 9 Tahun 1975 dinyatakan bahwa untuk melihat ada atau tidaknya kemampuan suami untuk menjamin keperluan hidup isteri-isteri dan anakanak, diperlukan salah satu surat dari surat-surat sebagai berikut: 1. Surat keterangan mengenai penghasilan suami yang ditanda tangani oleh bendahara tempat bekerja, 2 . Surat keterangan pajak penghasilan, 3. Surat keterangan lain yang dapat diterima oleh pengadilan, surat tersebut dapat menjadi pedoman majelis untuk menilai apakah pemohon dapat dinyatakan memiliki kemampuan untuk berpoligami atau tidak. Dalam konsep Islam dinyatakan bahwa salah satu syarat dianjurkannya seseorang untuk melakukan poligami, jika memiliki kemampuan ( $\left.B a^{\prime} a h\right)$. Untuk melihat ada atau tidaknya jaminan bahwa suami akan berlaku adil terhadap isteri-isteri dan anak-anak mereka dipelukan surat penyataan atau janji dari suami yang dibuat khusus dalam bentuk yang ditetapkan dalam pasal 41 Peraturan Pemerintah No. 9 Tahun $1975 .{ }^{17}$ Menurut dalam pengamatan penulis, mayoritas pelaku poligami yang berkembang dimasyarakat hanya sebagian saja yang melakukan praktik poligami dengan alasan sebagaimana yang telah diatur pada Undang-undang perkawinan. Karena kebanyakan para pelaku poligami ternyata melakukan poligami bukan karena istri menderita sakit atau isteri mandul, akan tetapi dengan alasan lain diluar itu, seperti hamil diluar nikah atau yang lainnya. Sebagai contoh kasus Putusan Nomor: 0348/Pdt.G/2009/PA.Plg. bahwa pengadilan Agama Palembang telah menjatuhkan putusan dalam perkara Izin Poligami yang diajukan oleh Pemohon dan Termohon yang bertempat tinggal di kelurahan Sentosa Kec. Seberang Ulu II Kota Palembang.

Putusan Nomor: 0502/Pdt.G/2012/PA.plg. bahwa pengadilan Agama Palembang telah menjatuhkan putusan dalam perkara Izin Poligami yang diajukan oleh Pemohon dan Termohon yang bertempat tinggal di Kelurahan Sukarame Kec. Sukarame Palembang. Dari hasil penelitian yang dilakukan melalui wawancara kepada hakim maupun kepada korban dari praktik poligami itu sendiri, baik kasus yang terjadi dipengadilan ataupun kasus yang diselesaikan secara kekeluargaan tanpa melibatkankan Pengadilan Agama. Penyebab suami melakukan poligami tanpa izin pengadilan disebabkan oleh: 1). Agar praktik poligaminya tidak diketahui orang lain termasuk keluarga dekatnya sendiri sebagai contoh kasus keputusan Pengadilan Agama Nomor: 0631/Pdt.G/2009/PA.Plg (Penipuan Status terhadap korban Poligami ilegal), 2). Tuntutan Profesi. Dengan berubahnya suasana dan keadaan serta meningkatnya penghasilan ekonomi dapat mengoda seseorang tertarik melakukan poligami. Diantara pelakunya berasal dari golongan publik figur, yakni mantan Walikota Palembang priode 2009-2013, Mantan DPRD Palembang Priode 2004-2009. (3). Tidak bisa memenuhi syarat yang telah ditentukan oleh Pengadilan Agama, salah satu contohnya: seseorang ingin melakukan poligami namun tidak dapat restu dari isteri yang pertama contoh kasus keputusan Pengadilan Agama Nomor: 0631/Pdt.G/2009/PA.Plg pernikahan tanpa mendapat izin isteri pertama terlebih dahulu, 4). Malu kepada keluarga dan kerabat untuk berpoligami, 5). Tidak mau repot mengurus persyaratan yang akan menyulitkan mencapai tujuan pelaku melakukan poligami disebabkan faktor keturunan keluarga beristri lebih dari satu. Sample kasus pada keluarga bapak Bullah yang memiliki 6 Isteri, 6). Menginginkan anak perempuan karena anak dari isteri pertama semuanya laki-laki.

\footnotetext{
${ }^{17}$ Direktorat Jendral Bimbingan Masyarakat Islam Kementerian Agama Republik Indonesia. Himpunan Peraturan Perundang-Undangan Perkawinanan. (Jakarta: Kementerian Agama RI, 2010), 28
} 
Tabel 2 Perkara Poligami di Pengadilan Agama

\begin{tabular}{clcc}
\hline No & \multicolumn{1}{c}{ Jenis Perkara } & Tahun & $\begin{array}{c}\text { Jumlah } \\
\text { perkara }\end{array}$ \\
\hline 1 & Izin poligami & $2008-2014$ & 28 \\
\hline 2 & $\begin{array}{l}\text { Pembatalan nikah di Pengadilan Agama karena } \\
\text { tidak memenuhi syarat berpoligami }\end{array}$ & $2008-2014$ & 28 \\
\hline 3 & $\begin{array}{l}\text { Sebagian Sample perkara Nikah poligami sirri } \\
\text { tanpa melibatkan pengadilan Agama }\end{array}$ & $2008-2014$ & 5 \\
\hline
\end{tabular}

Ada beberapa dampak negatif pemberlakuan Undang-Undang Perkawinan tahun 1974 yang menyulitkan masyarakat. Salah satunya adalah Undang-Undang Perkawinan tahun 1974 menganut asas monogami dan mencegah terjadinya poligami kecuali dengan syarat-syarat tertentu, tapi justru syarat tersebut menyulitkan bagi yang ingin berpoligami, padahal Islam mengajarkan kepada umatnya agar mempermudah dalam berbagai hal. Hasil riset di Pengadilan Agama Palembang menunjukkan bahwa volume pelanggaran peraturan poligami semakin banyak setiap tahunnya. Hal ini bisa dimaklumi karena memang persyaratan poligami dalam Undang-Undang Perkawinan tahun 1974 sangat sulit dipenuhi. Hal ini Bertentangan dengan dalil naqli : a. Surat An-Nisa' Ayat 3: menyatakan bahwa berpoligami hanya dipersyarat dengan satu syarat saja yaitu adil, Surat Al-Qosos Ayat 77: sesungguhnya Allah tidak menyukai kerusakan, b. Surat Albaqoroh ayat 173: siapa yang mendapati dalam keadaan darurat maka tidak ada dosa baginya selagi tidak melampaui batas, c. Hadits yang diriwatkan oleh Imam Al-Bukhori Artinya: Mudahkanlah jangan dipersulit. Bertentangan dengan aqli, apabila sesorang menginginkan sesuatu dan mempunyai kesempatan (diantaranya kebutuhan seksual) maka hal tersebut sungguh sangat rumit untuk dilarang. Argumen diatas dikuatkan juga dengan Berdasarkan hadist Nabi Muhammad S.A.W. ${ }^{18}$ Artinya: "Karena laki-laki akan terus berkurang dan kaum wanita semakin banyak sehingga terjadi kelak lima puluh wanita berbanding seorang laki-laki”.

Mempersulit perkara poligami juga bertentangan dengan kaidah Fiqhiyah: Hukum asal dari segala sesuatu adalah boleh, sehingga terdapat dalil yang mengharamkan الأصل . في الأشياء الإباحة حتى يدل دليل على التحريم menarik kemaslahatan, dan apabila berlawanan antara mafsadah dan maslahah didahulukan menolak mafsadah. درء المفاسد أولى من جلب المصالح, فإذا تعارض مفسده ومصلحة قدم Kebutuhan itu menduduki kedudukan darurat, baik hajat umum ataupun hajat individual ( الحاجة تنزل منزلة الضرورة عامة كانت أم خاصة). Tindakan pemimpin terhadap rakyatnya harus dihubungkan dengan kemaslahatan (تصرف الإمام على الرعية منوط بلمصلحة).

Berdasarkan fatwa para ulama, semua Ulama di dunia ini tidak ada yang menafikan atas kebolehan berpoligami, hanya saja sebagian dari pada Ulama Mu'ashirin atau modern seperti Muhammad Abduh, Syaltut, Imam Al-Ghazali dan Yusuf Al-Qaradhawi. Kesemuanya adalah Syuyukhul Azhar (Syeikh-syeikh alumnus Universitas al-Azhar) mengatakan diperbolehkan berpoligami jika dalam keadaan benar-benar darurat seperti isteri mandul, apabila bukan dalam keadaan darurat maka poligami tidak bisa dibenarkan.

${ }^{18}$ Rigoto, Suten. Poligami dari Berbagai Persepsi, (Jakarta: Gema Insani Press, 1996). 3 
Namun surat An-Nisa' ayat 3 tidak pernah mansukh. Menurut hemat penulis, dalam hukum Islam menyebutkan bahwa menikah lagi atau poligami itu tidak perlu ada persyaratan harus izin terlebih dahulu kepada pemerintah dalam sudut keabsahaan akad itu sendiri, cukup izin dari wali yang akan dinikahi anak perempuannya. Hanya saja keabsahan akad tersebut tidak secara mutlak karena telah bertentangan dengan pereturan yang telah pemerintah tetapkan. Jadi dapat disimpulkan bahwa pernikahan poligami tanpa izin Pengadilan Agama Sah menurut Agama Islam namun tidak sah secara agama. Sebagaimana perintah Allah dalam al-Qur'an surat An-Nisa: 59

Artinya: Hai orang-orang yang beriman, taatilah Allah dan taatilah Rasul (nya), dan ulil amri di antara kamu. Kemudian jika kamu berlainan pendapat tentang sesuatu, Maka kembalikanlah ia kepada Allah (Al Quran) dan Rasul (sunnahnya), jika kamu benar-benar beriman kepada Allah dan hari kemudian. yang demikian itu lebih utama (bagimu) dan lebih baik akibatnya. (Q.S. An-Nisa': 59). ${ }^{19}$

Menurut Undang-Undang Perkawinan dan Kompilasi Hukum Islam (KHI), perkawinan poligami harus dilakukan sesuai dengan peraturan perundang-undangan yang berlaku. Salah satu syaratnya adalah harus adanya izin dari isteri pertama dan izin dari pengadilan agama. Apabila syarat tersebut tidak dipenuhi, maka isteri pertama mempunyai hak untuk membatalkan perkawinan tersebut. Dari uraian tersebut timbul permasalahan diantaranya apakah undang-undang Nomor 1 Tahun 1974 tentang perkawinan sudah cukup mengatur perlindungan hukum terhadap isteri pertama sebagai akibat dari perkawinan poligami, bagaimana aturan perundang-undangan berkaitan dengan pembatalan perkawinan dikaitkan dengan perkawinan poligami dan bagaimana kedudukan (status) isteri dan anak-anak yang terlanjur dilahirkan dari perkawinan yang dibatalkan.

Seharusnya akibat hukum yang terdapat pada perkawinan poligami yang dilangsungkan tanpa izin pengadilan antaralain: 1. Perkawinan poligami yang dilakukan menjadi tidak sah, 2. Istri yang tidak sah, tidak mendapatkan harta milik bersama (hartagono-gini). 3. Karena status pernikahan tidak sah, maka status anak juga tidak sah dan tidak tercatat dalam catatan sipil. Namun para penegak hukum dipengadilan tidak mudah memutuskan sesuatu tanpa berkiblat terlebih dahulu kepada Undang-undang dan Kompilasi hukum Islam. Pasal 71 KHI Suatu perkawinan dapat dibatalkan apabila: seorang suami melakukan poligami tanpa izin Pengadilan Agama. Pasal 28: (1) Batalnya suatu perkawinan dimulai setelah keputusan Pengadilan mempunyai kekuatan hukum yang tetap dan berlaku sejak berlangsungnya perkawinan, (2) Keputusan tidak berlaku surut terhadap anak-anak yang dilahirkan dari perkawinan tersebut.

Menurut Hukum Adat, akibat hukum yang terdapat pada perkawinan poligami yang dilangsungkan tanpa izin pengadilan antara lain: a. Perkawinan poligami yang dilakukan menjadi tidak sah. b. Istri yang tidak sah, tidak mendapatkan harta milik bersama (harta gono-gini). c. Karena status pernikahan tidak sah, maka status anak juga tidak sah dan tidak tercatat dalam catatan sipil akibat hukum perkawinan poligami yang dilangsungkan tanpa izin pengadilan. Sanksi bagi pelaku yang melakukan poligami tanpa izin pengadilan, sebelum pemberlakuan UU Perkawinan No. 1/1974 di Indonesia, seorang laki-laki muslim cukup mudah untuk melakukan perkawinan poligami. diminta hanya untuk melaporkan perkawinan barunya kepada petugas pencatat perkawinan dan bersikap

19 Imad Dzaki Al-Barudi, Tafsir Al-Qur'an al-'Adim Lin Nisa', (Kairo: Maktabah At-Taufiqiyah), Diterjemahkan oleh Tim Penerjemah Pena, Tafsir Al-Qur'an Wanita, (Jakarta: Pena Pundi Aksara, Pusat, 2007), 7 
adil kepada para istrinya. Secara substansial Hukum Perkawinan merubah keadaan ini, walaupun sesungguhnya masih bersifat mendua di satu sisi, prinsip yang menyatakan bahwa perkawinan yang merupakan institusi monogami dianggap telah mendasari ketentuan-ketentuan hukum tersebut (Pasal 3) dan memang salah satu tujuan utama dari UU Perkawinan adalah untuk menekan tingkat perkawinan poligami di sisilain UU tersebut memperkenankan laki-laki untuk mempunyai lebih dari seorang istri jika ia mampu memenuhi persyaratan dari sejumlah ketentuan UU tersebut, diperbolehkan oleh agamanya, dan memperoleh izin dari pengadilan agama. ${ }^{20}$

Meskipun hak tersebut tetap dipertahankan, namun secara prosedur administratifnya tidaklah mudah, secara umum ia membatasi kemungkinan terjadinya penggunaan hak tersebut secara sewenang-wenang. Ketentuan yang sama tetap dipertahankan dalam Kompilasi Hukum Indonesia (KHI) yang ditetapkan pada tahun 1991. Pengadilan dalam hal ini memainkan peran penting dalam pemberian izin kepada suami untuk berpoligami. Meskipun demikian, baik UU No. 1 /1974 maupun KHI tidak mencantumkan sanksi hukum terhadap pihak yang melakukan pelanggaran. Sanksi poligami diatur dalam Peraturan Pemerintah No. 9 tahun 1975 tentang Pelaksanaan UU No.1/1974, disebutlkan bahwa pelaku poligami tanpa izin Pengadilan dapat dijatuhi hukuman denda Rp. 7.500. Sanksi hukum juga dikenakan kepada petugas pencatat yang melakukan pencatatan perkawinan seorang suami yang akan berpoligami tanpa izin pengadilan dengan hukuman kurungan maksimal 3 bulan atau denda maksimal Rp.7.500,-. Dalam pada itu, hukuman yang relatif berat dijatuhkan bagi Pegawai Negeri Sipil yang berpoligami di luar ketentuan yang ditetapkan. ${ }^{21}$

Disebutkan dalam Surat Edaran No. 48/SE/1990 tentang Petunjuk Pelaksanaan PP No. 45/1990 tentang perubahan atas PP No. 1983 tentang Izin Perkawinan dan Perceraian Pegawai Negeri Sipil, bahwa PNS dan atau atasan/pejabat, kecuali Pegawai Bulanan di samping pensiunan, dijatuhi salah satu hukuman disiplin berat berdasarkan PP No. 30/1980 tentang Peraturan Disiplin PNS. Berbagai ketentuan dalam UU Perkawinan No. 1/1974 maupun dalam KHI mengenai poligami di atas pada dasarnya tidak bertentangan dengan konsep mazhab-mazhab konvensional, termasuk madzhab Syafi'i. Hampir sama dengan Hukum Keluarga Malaysia, persyaratan bagi seorang suami yang ingin berpoligami juga dihubungkan dengan kewajiban suami yang diatur dalam konsepsi fikih tradisional, yakni kemampuan memberi nafkah dan dapat berlaku adil kepada para istri.

Begitu pula dengan kondisi darurat istri yang dimadu tampaknya dikaitkan dengan alasan fasakh. Lebih jauh produk hukum ini juga diorientasikan untuk mengangkat status wanita dan memberikan perlindungan kepada mereka, suatu hal yang sejalan dengan semangat al-Qur'an dan Sunnah Rasul. Meskipun kini perkawinan poligami telah dan agaknya akan menjadi hal yang jarang terjadi di Indonesia, namun efektifas hukum yang mengatur poligami kelihatannya masih diragukan. Di antara faktor penyebabnya adalah sanksi hukum atas pelanggaran UU ini, denda Rp. 7.500,- atau penjara 3 bulan, sudah dianggap tidak sesuai kondisi saat ini. Hukuman tersebut tidak cukup keras mencegah pelanggaran hukum tersebut. Selain itu masih terjadinya dualisme hukum di Indonesia: Hukum Islam tradisional versus hukum negara, mengakibatkan para pelaku poligami lebih memilih berlindung pada hukum Islam tradisional yang mengabsahkan

\footnotetext{
${ }^{20}$ Imad Dzaki Al-Barudi, Tafsir Al-Qur'an, 34

${ }^{21}$ Bahder Johan, Wawancara (Palembang. 05 Januari 2015).
} 
poligami tanpa khawatir akan dijatuhi hukuman seperti yang diberlakukan oleh hukum positif. $^{22}$

\section{Kesimpulan}

Setelah memaparkan semua masalah yang telah penulis uraikan penulis mengambil kesimpulan sebagai berikut: Penyebab suami melakukan poligami tanpa izin Pengadilan Agama dikarenakan: praktik poligaminya tidak diketahui orang lain, tuntutan profesi, tidak bisa memenuhi syarat yang telah ditentukan oleh Pengadilan Agama, malu kepada keluarga dan kerabat untuk berpoligami, tidak mau repot mengurus persyaratan yang akan menyulitkan mencapai keinginannya, karena terlanjur hamil. Hukum Poligami tanpa izin Pengadilan Agama, dipandang dari sudut pandang hukum Islam sah-sah saja selagi memenuhi syarat dan rukun pernikahan itu sendiri, namun jika dilihat dari esensi UndangUndang Perkawinan 1974 dan Kompilasi Hukum Islam (KHI) mengisyaratkan tidak dianggap sah apabila pernikahan tersebut tidak tercatat oleh aparatur pencatat pernikahan. Sanksi poligami diatur dalam Peraturan Pemerintah No.9 tahun 1975 tentang Pelaksanaan UU No.1/1974, disebutlkan bahwa pelaku poligami tanpa izin Pengadilan dapat dijatuhi hukuman denda Rp. 7.500,-.

\section{Daftar Pustaka}

Abdurahman. 1992. Perkawinan Dalam Syari'at Islam. (Jakarta: Renika Cipta, dan Melton Putra).

Al-Barudi, Imad Dzaki. 2007. Tafsir Al-Qur'an al-'Adim Lin Nisa', Maktabah AtTaufiqiyah, Kairo. Diterjemahkan oleh Tim Penerjemah Pena. Tafsir Al-Qur'an Wanita. (Jakarta Pusat.Pena Pundi Aksara).

Alfianty, Rani. 2011, Tesis, dengan Judul Pembatalan Perkawinan Poligami Beda Kewarganegaraan Tanpa Izin Isteri Disertai Dengan Pemalsuan Identitas (Studi Kasus Putusan Pengadilan Agama Depok Nomor 324/Pdt.G/2006/PA.Dpk). Tesis, Universitas Indonesia, 2011.

Asshiddiqie, Jimly dan Ali Safa'at. 2006. Teori Hans Kelsen Tentang Hukum. (Jakarta: Setjen \& Kepaniteraan MK-RI).

D. Snardjo, Nazwier dan Ilyas, Yusrani. 1992. Tuntunan Keluarga. (Jakarta Pusat: Kalam Mulia).

Direktorat Jendral Bimbingan Masyarakat Islam Kementerian Agama republik Indonesia. 2010. Himpunan Peraturan Perundang-Undangan Perkawinanan. Jakarta: Kementerian Agama.

Departemen Agama. 2004. Pedoman Pembantu Pegawai Pencatat Nikah, Proyek Peningkatan Tenaga Keagamaan Direktorat Jendral Bimbingan Masyarakat Islam dan Penyelengaraan Haji. Jakarta: Departemen Agama R.I

Gazaly, Abdurrahamn. 2003. Fiqih Munakahat. (Bogor: Kencana).

Ibrahim, Duski. Opini 06/12/ 2013. Keluarga sebagai Basis Kependudukan, Sumatera Ekspress.

Moleong, Lexy. J. 1991. Metode Penelitian Kualitatif. (Bandung: Percetakan Rusda). Ramulyo, Idris. 1996. Hukum Perkawinan Islam. (Jakarta: Bumi Askara).

Rigoto, Suten. 1996. Poligami dari Berbagai Persepsi. (Jakarta: Gema Insani Press).

22 Bahder Johan, Wawancara (Palembang. 05 Januari 2015 
Syachdin, Lianora Sinaga Jubair. Jurnal Ilmiah Universitas Tadulako, Penegakan Hukum Penyalahgunaan Izin Tinggal Orang Asing Di Kota Palu (Studi Kasus Di Imigrasi Klas I Palu), 2017, (http://jurnal.untad.ac.id/jurnal/index.php).

Sari, Elisa. Rina Dwiarti. Pendekatan Hierarki Abraham Maslow Pada Prestasi Kerja karyawan PT. Madubaru (Pg Madukismo). Jurnal Perilaku dan Strategi Bisnis 6 no.1, 2018.

Ulwan, Abdullah Nasikh. 2007. Pendidikan Anak dalam Islam. Jakarta: Pustaka Amani. 